\title{
ESTIMATION OF CROP COEFFICIENT VARIATION THROUGH SATELLITE VNIR SPECTRAL DATA
}

\author{
M. A. Badr ${ }^{1}$, M. A. El-Shirbeny ${ }^{1}$, M. Y. El-Ansary ${ }^{2}$ and \\ M. A. Awad'.
}

\section{ABSTRACT}

Crop coefficient is a principle factor to estimate crop water consumption. Traditionally Kc estimated from Kc $=E T c / E T o$ or from the FAO table. The aim of this paper is to develop a simple model to estimate $K c_{N D V I}$ using remote sensing technique. To develop such model this work was cared out in salhia area on three winter crops wheat, potato and sugar beet, on certain dates of their growing seasons of 2013-2014. Landsat 8 and Landsat7, the Enhanced Thematic Mapper Plus (ETM+) satellites were used to generate NDVI values on these dates. The values of NDVI and the Kc estimated from $K c=E T c / E T o$ were used to established $K c_{N D V I}$ equation. The following equation $K c_{N D V I}=1.259 \mathrm{NDVI}+0.034$ is the developed model with $r=0.92$. To validate this model the values of Kc predicted using it at six dates on wheat and potato crops raised on same site on 2014-2015 growing season was compared with estimated $K c_{F A O}$ on same dates. The validation give a good results with $r=0.98$ for the two crops.

Keywords: Normalized deference vegetation index (NDVI), landsat8, Landsat 7 ETM+; Crop coefficient $\left(K_{c}\right)$.

\section{INTRODUCTION}

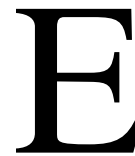
gypt is facing and continues to face serious water shortage, which necessitate an optimum water management for various water uses. Agriculture depends mainly on irrigation. therefore the optimization of crop water consumption is a must. Crop evapotranspiration $\left(\mathrm{ET}_{\mathrm{c}}\right)$ is used to estimate water needs. $\mathrm{ET}_{\mathrm{c}}$ is a function of two parameters reference evapotranspiration $\left(\mathrm{ET}_{\mathrm{o}}\right)$, and crop coefficient $\left(\mathrm{K}_{\mathrm{c}}\right)$.

$$
E T_{c}=E T_{o} \times K_{c}
$$

\footnotetext{
${ }^{1}$ National Authority for Remote Sensing and Space Sciences (NARSS), Egypt.

${ }^{2}$ Department of Agricultural Engineering, Faculty of Agriculture, Benha University, Egypt.
} 
$\mathrm{ET}_{\mathrm{o}}$ have traditionally been derived from meteorological data. The reference crop is typically grass or alfalfa under well-watered conditions. The height of the grass reference should be at least 8 and no more than 15 $\mathrm{cm}$ (Allen et al., 2005). $K_{c}$ values are specific to each crop. During the crop growing season, the value of $\mathrm{K}_{\mathrm{c}}$ for most agricultural crops takes upward trend from a minimum value at germination, and expressed as a smooth continuous function in time until a maximum $\mathrm{K}_{\mathrm{c}}$ is reached at about full canopy cover and then tends to decline at a point after reached the full cover in the growing season (Kamble et al., 2013).

The traditional method to calculate $\mathrm{K}_{\mathrm{c}}$ by applying the eq. 1 where $\mathrm{K}_{\mathrm{c}}$ is the ratio of $\mathrm{ET}_{\mathrm{c}}$ to $\mathrm{ET}_{\mathrm{o}}$. The United Nations Food and Agriculture Organization (FAO) established tables of $\mathrm{K}_{\mathrm{c}}$ for different crops which could be used in water management. Recently remote sensing technique is considered an important tool to estimate Kc. The researchers found that the relationships between vegetation indices (VI) and crop coefficients $\left(\mathrm{K}_{\mathrm{cs}}\right)$ are usually observed for the single crop coefficient. VI was developed with the launch of the first satellites used for vegetation monitoring in the early 1970s (Rouse et al., 1973; Huete and Glenn, 2011). The relations $\left(K_{c}-V I\right)$ have been developed for individual and mixed crops in agricultural regions starting nearly 30 years ago (Neale, 1983). Tasumi and Allen (2007) explained that satellite-based remote sensing is a robust, economic and efficient tool for estimating actual ET and developing $\mathrm{K}_{\mathrm{c}}$ curves. This technique can cover large scale of fields at the same time so that large populations of $\mathrm{ET}_{\mathrm{o}}$ and $\mathrm{K}_{\mathrm{c}}$ can be used to develop representative mean values. Normalized difference vegetation index (NDVI) one of the most common VI. It has been used extensively for crop yield assessment, vegetation monitoring and drought detection, Higher NDVI indicates a greater level of photosynthetic activity (Sellers 1985; Tucker 1979). The NDVI captures the sharp contrast in reflection of light from green leaves between the Red and NIR wavelengths. Red light is strongly absorbed by chlorophyll $\mathrm{a}$ and $\mathrm{b}$ in leaves, interacting mostly with the top layers of a dense canopy, but nearly all of the NIR is transmitted, reflected or scattered by the mesophyll structure in leaves, penetrating deep into the canopy and interacting with multiple leaf layers 
(Glenn et al., 2008). This light is received by a downward-looking sensor sensitive to the NIR band. Most of the satellites have sensors that can measure in visible and near infrared region (El-Shirbeny et al., 2014). Many studies have shown a high correlation between NDVI and biophysical characteristics of plants, including fractional cover (fc), leaf area index (LAI); chlorophyll content; and wet and dry biomass (Glenn et al., 2008). NDVI is also strongly correlated with physiological processes that depend on light absorption by the canopy, including ET, yield, or net and gross primary productivity. NDVI values fall between 1.0 and +1.0 , tacking negative values with water, slightly positive values with soil, and vegetation having increasingly high values approaching 0.95 for very dense vegetation cover (Bannari et al., 1995). Many of researchers have used multispectral vegetation indices extracted from remote sensing to estimate $\mathrm{K}_{\mathrm{c}}$ values at the field scale for maize, wheat, cotton (Hunsaker et al., 2005, Bausch and Neale 1989, El-Shirbeny et al., 2014), and beans (Irmak 2010). (Bausch and Neale 1989) produced application of ground based physical remote sensing technique to relate seasonal NDVI to $\mathrm{K}_{\mathrm{c}}$. The main aim of this study is a) to investigate the applicability of time-series Landsat8 and Landsat7 NDVI data to develop a simple model to calculate $K_{c}$ values under the Egyptian conditions and b) to validate the results by comparing it with $\mathrm{Kc}$ FAO values which adjusted for local climate conditions.

\section{MATERIALS AND METHODS:}

\section{Study Area}

El-Salhia project was selected as a study area which is located at the eastern part from Nile Delta a. It is bounded by $30^{\circ} 22^{\prime} 35^{\prime \prime}$ and $30^{\circ} 31^{\prime}$ 19" latitudes and $31^{\circ} 55^{\prime} 24^{\prime \prime}$ and $32^{\circ} 02^{\prime} 38^{\prime \prime}$ longitudes as shown in Fig. 1. The whole area of the project is about 32857 Fed. Two irrigation systems are in use in the project; central pivots and drip irrigation. Pivot irrigation is used for field crops and drip irrigation is used for orchards trees. The project has about 100 pivots. Each pivot unit irrigates an area of about $151 \mathrm{Fed}$. The common pivots length in the project is about 450 meter. 


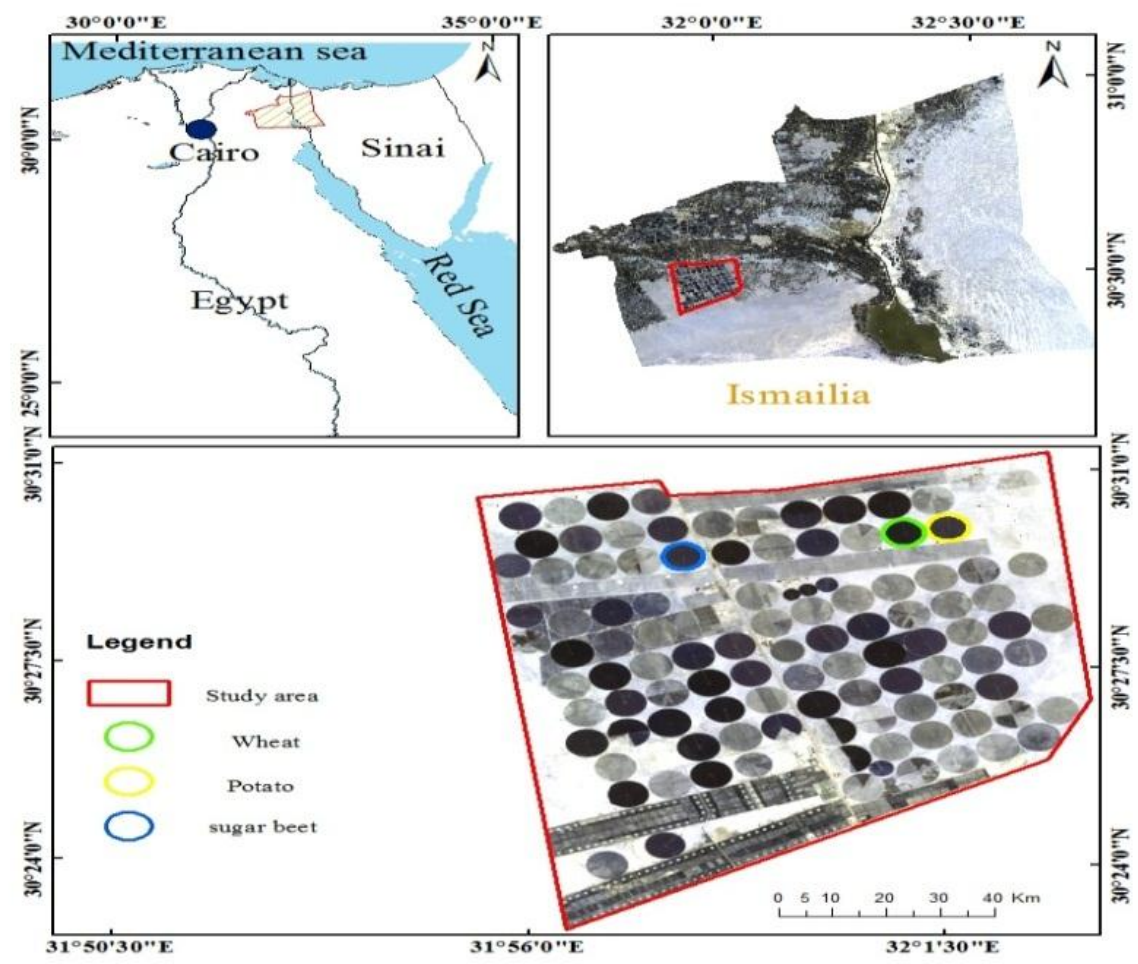

Fig. 1: Location map of the study area

\section{Climate Conditions}

In general, the climate in study area is a dry arid according to Köppen Climate Classification System, where precipitation is less than $50 \%$ of potential evapotranspiration. Annual average temperature is over $18^{\circ} \mathrm{C}$. The average rainfall is approximately $20 \mathrm{~mm}$ /year. The maximum values of rainfall are registered in January with an average value of $6.9 \mathrm{~mm}$. The average maximum value of temperature reach $34.6^{\circ} \mathrm{C}$ in June while January represents the coldest month $19.0{ }^{\circ} \mathrm{C}$.

\section{Remote Sensing Data Availability}

A series of Landsat8 and Landsat 7 ETM+ data were collected from the U.S. geological survey earth explorer site (http://earthexplorer.usgs.gov/) to calculate NDVI and water deficit index (WDI). For model development satellite data of winter season 2013-2014 was used on Dec. $17^{\text {th }}, 2013$, Jan. $2^{\text {nd }}, 2014$, Feb. $11^{\text {th }}, 2014$, Mar. $15^{\text {th }}, 2014$, Mar. $31^{\text {st }}$, 
2014, Apr. $16^{\text {th }}, 2014$ and May. $2^{\text {nd }}$, 2014. Three cultivated crops wheat, sugar beet, potato were raised and taken for this investigation.

For validating the results the same procedures was carried out for 20142015 winter season but only for two crops raised in this season wheat, potato. Satellite data for model validation were acquired on Dec. $4^{\text {th }}$, 2014, Dec. $12^{\text {th }}, 2014$, Dec. $28^{\text {th }}, 2014$, Jan. $29^{\text {th }}, 2015$, Feb. $6^{\text {th }}, 2015$, Mar. $2^{\text {nd }}, 2015$, Apr. $3^{\text {rd }}, 2015$, Apr. $19^{\text {th }}, 2015$ and May. $5^{\text {th }}, 2015$.

\section{Model Development}

\section{Crop coefficient $(\mathrm{Kc})$ estimation using traditional method:}

$\mathrm{Kc}$ is a factor which indicates the ratio between the (ETc) and the (ETo). It depends on many parameters such as crop type, crop stage and crop management. So, the Kc can be estimated from the following equation:

$$
\mathrm{K}_{\mathrm{c}}=\frac{\mathrm{ET}_{\mathrm{c}}}{\mathrm{ET}_{\mathrm{o}}}
$$

\section{WDI and ETc Estimation:}

$\mathrm{ET}_{\mathrm{c}}$ was estimated by using the following relation between both of ETc, $\mathrm{ET}_{\mathrm{a}}$ and the Water Deficit Index (WDI) which account for soil moisture content and is an indicator for water shortage and stress effect on the crop.

$$
\mathrm{WDI}=1-\left(\frac{\mathrm{ETa}}{\mathrm{ETc}}\right)
$$

Where: WDI is the water deficit index (dimensionless), $\mathrm{ET}_{\mathrm{a}}$, is the actual crop evapotranspiration ( $\mathrm{mm} /$ day) and $\mathrm{ET}_{\mathrm{c}}$ is the crop evapotranspiration (mm/day).

Remote sensing is a promising tool which introduces vital information about the surface and reflects the actual statue of the different surface features due to different conditions and heterogeneity. $\mathrm{ET}_{\mathrm{c}}$ was estimated by using eq. 3 and produced in map format using remote sensing satellite data. $\mathrm{ET}_{\mathrm{a}}$ was estimated using of the triangle method which was proposed by (Jiang and Islam 1999, 2001) and improved by (Jiang and Islam, 2003). This method is based on the $\mathrm{P}-\mathrm{T}$ (Priestley-Taylor) equation and represents a simplified remote sensing model for $\mathrm{ET}_{\mathrm{a}}$ estimation. This method was applied at this study area in the 2013/2014 winter season by (Baioumy et al., 2016) and he got responsible results in estimating $\mathrm{ET}_{\mathrm{a}}$ 
using this method. Vegetation and water stress indexes calculated based on remotely sensed data can provide spatial and temporal information. When water becomes limited the $\mathrm{ET}_{\mathrm{a}}$ rate will fall below the potential rate. (Moran et al., 1994). The WDI ranges from 0 (no stress) to 1 (maximum stress).

\section{Reference evapotranspiration $\mathbf{E T}_{\mathbf{0}}$ calculation:}

Daily calculation of the $\mathrm{ET}_{\mathrm{o}}$ is one of the most important tools used to determine the water requirements of different crops. Penman-Monteith equation adopted by the FAO as one of the methods used to estimate the $\mathrm{ET}_{\mathrm{o}}$, which can be globally applicable and it is based on meteorological data variables (wind speed, temperature, relative humidity and radiation), all the details have been mentioned in the Irrigation and Drainage Paper no. 56 (Allen et al., 1998). The formulation of the equation is as follows:

$$
\text { ETo }=\frac{\left.\left[0.408 \Delta\left(\mathrm{R}_{\mathrm{n}}-\mathrm{G}\right)+\gamma\right) \frac{900}{(\mathrm{~T}+237)} \mathrm{u}_{2}\left(\mathrm{e}_{\mathrm{s}}-\mathrm{e}_{\mathrm{a}}\right)\right]}{\Delta+\gamma\left(1+0.34 \mathrm{u}_{2}\right)}
$$

Where $\mathrm{Rn}$ is net radiation at crop surface $\mathrm{MJ} / \mathrm{m}^{2}$ day, $\mathrm{G}$ is soil heat flux density $\mathrm{MJ} / \mathrm{m}^{2}$ day, $\mathrm{T}$ is air temperature at $2 \mathrm{~m}$ height ${ }^{0} \mathrm{C}, \mathrm{u}_{2}$ is wind speed at $2 \mathrm{~m}$ height $\mathrm{m} / \mathrm{s}$, es-ea is saturation vapor pressure deficit $\mathrm{kPa}, \Delta$ is slope vapor pressure curve $\mathrm{kPa} /{ }^{0} \mathrm{C}$, and $\gamma$ is psychometric constant $\mathrm{kPa} / 0 \mathrm{C}$.

In devising Penman-Monteith equation is used a hypothetical green grass reference surface that is actively growing and is adequately watered with a surface resistance of $70 \mathrm{~s} \mathrm{~m}^{-1}$, with an assumed height of $0.12 \mathrm{~m}$, and an albedo of 0.23 (Allen et al., 1998).

\section{NDVI and Ke relationship:}

NDVI was derived from remote sensing data using two bands the red and near-infrared bands. It depends on reflectance of the plant in the red (R) and near-infrared (NIR) bands of the spectrum. This vegetation index is given by:

$$
\mathrm{NDVI}=\frac{(\mathrm{NIR}-\mathrm{R})}{(\mathrm{NIR}+\mathrm{R})}
$$

Where: $\mathrm{R}$ is the reflectance in the red region and NIR is the reflectance in near infrared region of the spectrum. The researchers agreed that the 
NDVI values are well correlated with vegetation parameters like net primary productivity, leaf area index and gross primary productivity (Gamon et al., 1995). For modeling the $\mathrm{K}_{\mathrm{c}}$-NDVI relationship we must calculate values of $\mathrm{K}_{\mathrm{c}}$, as well as NDVI from the same pixel, and adjusted $\mathrm{Kc}_{\mathrm{FAO}}$ values were used for validation purposes. $\mathrm{K}_{\mathrm{c}}$ values as well as NDVI are available at different dates for the study area along the winter season. NDVI pixels used were located as close as possible to the center of the pivot, to avoid mixed pixel problems. Three winter crops are wheat, sugar beet and potato raised during the 2013/2014 winter season were used to generate values of both $\mathrm{K}_{\mathrm{c}}$ and NDVI. Generated values is to be used in a Linear regression model to obtain the designed relationship in the form (Kc $\left.{ }_{N D V I}=a \times N D V I \pm b\right)$. The coefficient of determination of the above model is used to assess the degree of fit.

\section{Model validation:}

\section{Adjusted $\mathrm{Kc}_{\mathrm{FAO}}$ Calculation for local climate conditions:}

The values of the calculated $\mathrm{Kc}$ FAO are used to compare it with Kc NDVI. The FAO procedure for adjusting $\mathrm{K}_{\mathrm{c}}$ values uses mean daily minimum relative humidity and wind speed. For climates with $\mathrm{RH}_{\min }$ greater than or less than $45 \%$ or with mean wind speeds at 2 m over grass $\left(\mathrm{u}_{2}\right)$ that are more than or less than $2.0 \mathrm{~m} / \mathrm{s}$, the standardized values for all $\mathrm{K}_{\mathrm{c}}$ mid from FAO-56 and for $\mathrm{K}_{\mathrm{c}}$ end are adjusted as:

$$
\begin{gathered}
\mathrm{K}_{\mathrm{c} \text { mid/end }}=\mathrm{K}_{\mathrm{c} \mathrm{mid} / \mathrm{end}(\mathrm{table})}+\left[0.04\left(\mathrm{u}_{2}-2\right)-0.004\left(\mathrm{RH}_{\min }-\right.\right. \\
45)]\left(\frac{\mathrm{h}}{3}\right)^{0.3}
\end{gathered}
$$

Where $\left(\mathrm{K}_{\mathrm{c}}\right.$ mid/end (table)) is the value for $\mathrm{K}_{\mathrm{c}}$ mid and $\mathrm{K}_{\mathrm{c}}$ end for the standardized climate and $(\mathrm{h})$ is the mean maximum plant height $(\mathrm{m})$ during the midseason period, or full cover period. The Previous equation is valid for $\mathrm{h}<20 \mathrm{~m}$ (Allen et al. 1998 and 2005). The values for $\mathrm{RH}_{\text {min }}$ and $\mathrm{u} 2$ need only be approximate values averaged over the mid-season and late-season periods. $\mathrm{K}_{\mathrm{c}}$ ini for local climate conditions almost the same in table of the FAO, $\mathrm{K}_{\mathrm{c}}$ ini is adjusted as:

$$
\mathrm{Kc}_{\text {ini }}=\mathrm{fw} \times \mathrm{Kc}_{\text {ini }(\mathrm{Tab})}
$$

Where $f w$ the fraction of surfaced wetted by irrigation or rain [0 - 1], $K_{c}$ ini (Tab) the value for $K_{c}$ ini is the value for $K_{c}$ ini for the standardized climate. In our case $\mathrm{fw}=1$. 


\section{RESULTS AND DISCUSSION:}

\section{Development of $\mathrm{Kc}_{\text {NDVI }}$ model:}

In this section we develop the relationship between Kc and NDVI using three winter crops which are wheat, sugar beet and potato. Table 1 represents the average values of Kc and NDVI for the three winter crops during the season.

Table. 1: average values of $K_{c}$ and NDVI for the three winter crops during the season.

\begin{tabular}{|c|c|c|c|}
\hline Crop & Date & NDVI & $\mathrm{K}_{\mathrm{c}}$ \\
\hline \multirow{5}{*}{ Wheat } & $12 / 17 / 2013$ & 0.56 & 0.62 \\
\cline { 2 - 4 } & $1 / 2 / 2014$ & 0.68 & 1.0 \\
\cline { 2 - 4 } & $2 / 11 / 2014$ & 0.81 & 1.16 \\
\cline { 2 - 4 } & $3 / 15 / 2014$ & 0.75 & 1.07 \\
\cline { 2 - 4 } & $3 / 31 / 2014$ & 0.50 & 0.77 \\
\cline { 2 - 4 } & $5 / 2 / 2014$ & 0.23 & 0.20 \\
\hline \multirow{5}{*}{ Sugar beet } & $1 / 2 / 2014$ & 0.74 & 0.89 \\
\cline { 2 - 4 } & $2 / 11 / 2014$ & 0.83 & 1.03 \\
\cline { 2 - 4 } & $3 / 15 / 2014$ & 0.78 & 0.96 \\
\cline { 2 - 4 } & $3 / 31 / 2014$ & 0.74 & 1.02 \\
\cline { 2 - 4 } & $4 / 16 / 2014$ & 0.77 & 1.10 \\
\cline { 2 - 4 } & $5 / 2 / 2014$ & 0.75 & 0.84 \\
\hline \multirow{5}{*}{ Potato } & $2 / 11 / 2014$ & 0.25 & 0.41 \\
\cline { 2 - 4 } & $3 / 15 / 2014$ & 0.75 & 0.86 \\
\cline { 2 - 4 } & $3 / 31 / 2014$ & 0.67 & 0.85 \\
\cline { 2 - 4 } & $4 / 16 / 2014$ & 0.56 & 0.87 \\
\hline
\end{tabular}

Fig. 2 shows the relationship between NDVI and the $\mathrm{K}_{\mathrm{c}}$ for the crops in this investigation. There was a strong relation between NDVI and the $\mathrm{K}_{c}$. The combined relationship between NDVI and the $\mathrm{K}_{\mathrm{c}}$ is:

$$
\mathrm{Kc}_{\mathrm{NDVI}}=1.259 \mathrm{NDVI}+0.034
$$

The coefficient $\mathrm{r}$ is 0.92 , which shows that there is a potential for established $\mathrm{K}_{\mathrm{c} \text { NDVI }}$ model. 


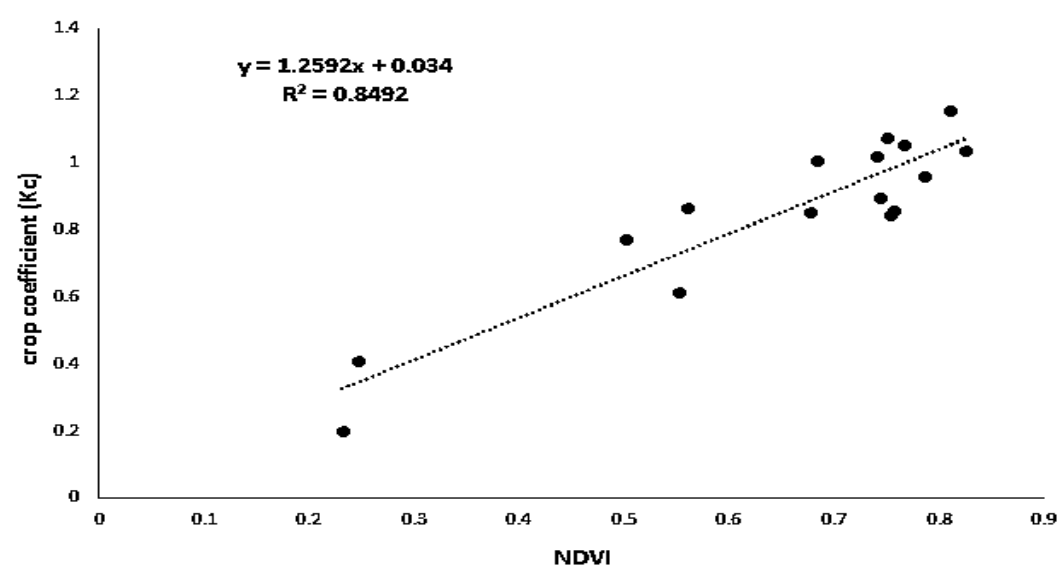

Fig. 2: Relationship between NDVI and $\mathrm{K}_{\mathrm{cs}}$ for wheat, sugar beet and potato.

\section{Validation of Kc $\mathbf{~ N D V I}_{\text {model: }}$}

To validate the $\mathrm{Kc}_{\mathrm{NDVI}}$ model values of predicted $\mathrm{Kc}_{\mathrm{NDVI}}$ using eq. 8 is to be compared with calculated $\mathrm{Kc}_{\mathrm{FAO}}$ using eq. 7 for two crops raised on 2014-2015 season on el-Salhia area. For wheat dates were $12^{\text {th }}, 2014$, Dec. $28^{\text {th }}, 2014$, Jan. $29^{\text {th }}, 2015$, Mar. $2^{\text {nd }}, 2015$, Apr. $3^{\text {rd }}, 2015$, Apr. $19^{\text {th }}$, 2015 and May. $5^{\text {th }}, 2015$. For potato dates were Dec. $4^{\text {th }}, 2014,12^{\text {th }}$, 2014, Dec. $28^{\text {th }}$, 2014, Jan. $29^{\text {th }}$, 2015, Feb. $6^{\text {th }}, 2015$, Mar. $2^{\text {nd }}, 2015$.

Fig. 3 and 4 shows the $\mathrm{Kc}_{\mathrm{NDVI}}$ predicted values vs $\mathrm{Kc}_{\mathrm{FAO}}$ for wheat and potato respectively where $r$ for the two crops was 0.988 and 0.989 respectively to indicate the relation between both methods.

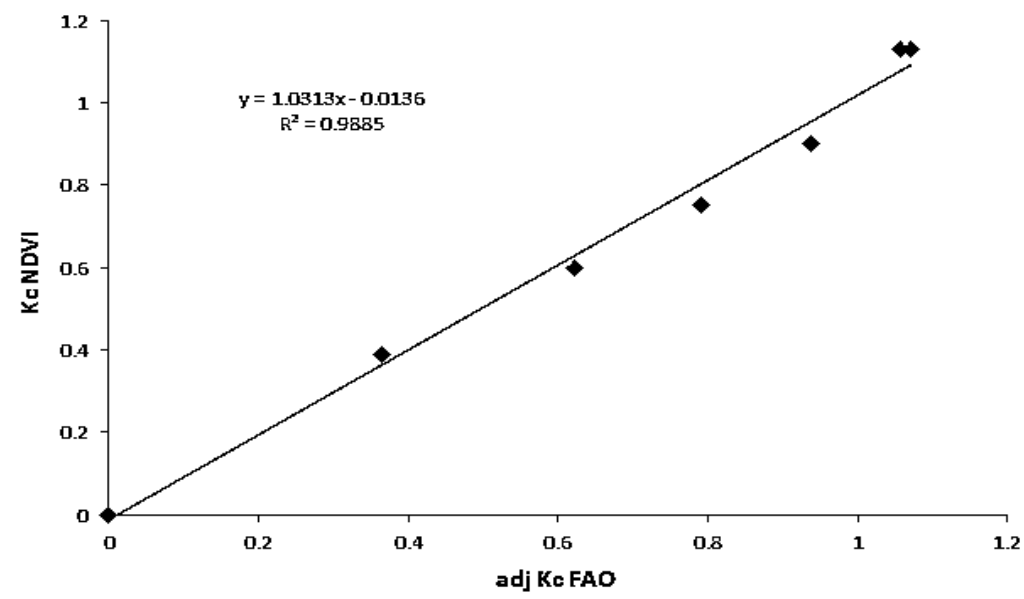

Fig. 3: Wheat regression scatter plots of adjusted $\mathrm{Kc}_{\mathrm{FAO}}$ and $\mathrm{Kc} \mathrm{NDVI}_{\mathrm{I}}$ 


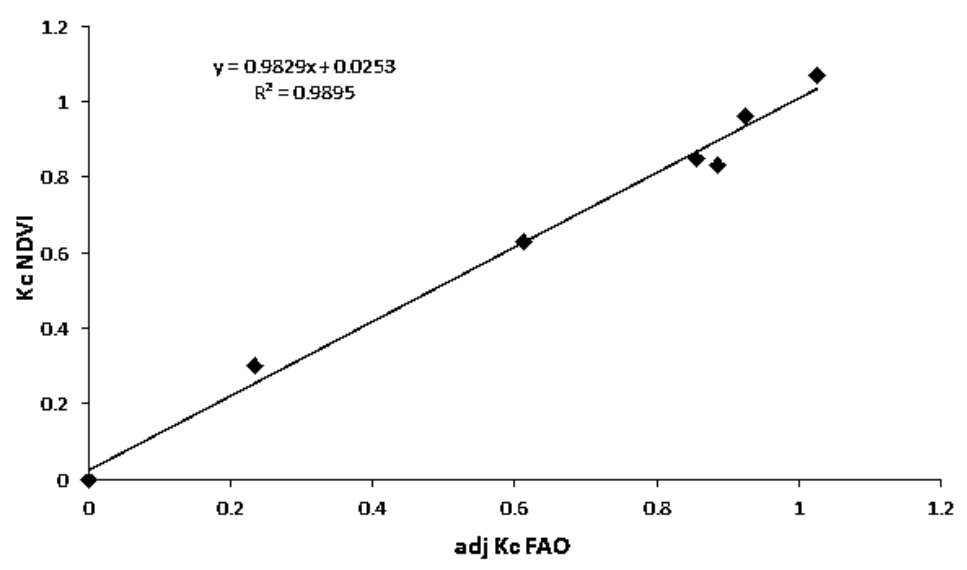

Fig. 4: potato regression scatter plots of adjusted $\mathrm{Kc}_{\mathrm{FAO}}$ and $\mathrm{Kc} \mathrm{NDVI}_{\mathrm{N}}$

Therefore it may be concluded that the $\mathrm{Kc}_{\mathrm{NDVI}}$ method could be used to predict Kc for various crops. These results agree with Hunsaker et al., 2005, Bausch and Neale 1989, El-Shirbeny et al., 2014, Irmak 2010 and Bausch and Neale 1989.

\section{Conclusion:}

The purpose of this work was to develop a model to estimate Kc using remote sensing technique. NDVI extracted from Landsat8 and Landsat 7 ETM+ satellite data for three winter crops wheat, sugar beet and potato and estimated Kc from ETc and ETo for same crops at same dates were used to develop the model during 7 dates through it's growing season 2013-2014. The following equation $\mathrm{Kc}_{\mathrm{NDVI}}=1.259 \mathrm{NDVI}+0.034$ is the developed model with $\mathrm{r}=0.92$. This model was validated with comparing the $\mathrm{Kc}_{\mathrm{NDVI}}$ with the estimated $\mathrm{Kc}_{\mathrm{FAO}}$ using two winter crops wheat and potato at season 2014-2015. The validation gave a good results with $r=0.98$ for the two crops.

\section{REFERENCE:}

Allen, R.G., Pereira, L.S., Raes, D. and Smith, M. (1998). Crop Evapotranspiration-Guidelines for Computing Crop Water Requirements-FAO Irrigation and Drainage. FAO56, Rome, Italy. 
Allen, R.G., Pereira, L.S., Smith, M., Raes, D. and Wright, J.L. (2005). The FAO-56 dual crop coefficient method for predicting evaporation from soil and application extensions. J. Irrig. Drain. Eng. 131: 2-13.

Allen, R.G., Walter, I.A., Elliot, R.L., Howell, T.A., Itenfisu, D., Jensen, M.E. and Snyder, R.L. (2005b). The ASCE Standardized Reference Evaportranspiration Equation. American Society of Civil Engineers: Danvers, MA, USA: 59.

Baioumy, E., El-Shirbeny, M., El-Ansary, M. and Awad, M. (2016). Estimation of Regional Evapotranspiration Based on Tri-Angle Method Using Thermal and VNIR Data. Inter. J. Plant Soil Sci. 10(6): 1-15.

Bannari, A., Morin, D., Bonn, F. and Huete, A. (1995). A review of vegetation indices. Inter. J. Remote Sensing 13: 85-120.

Bausch, W.C. and Neale, C.M.U. (1989). Spectral inputs improve maize crop coefficients and irrigation scheduling. Trans. ASAE, 32: 1901-1908.

Doorenbos, J. and Pruitt, W.O. (1977). Crop water requirement: food and agriculture organization of the United Nations, FAO Irrig. Drain.: 24, Rome, Italy.

El-Shirbeny, M.A., Ali, A.M., Badr, M.A. and Bauomy, E.M. (2014). Assessment of wheat crop coefficient using remote sensing techniques. World Res. J. Agric. Sci. 1(2): 012-016.

Gamon, J.A., Field, C.B., Goulden, M., Griffn, K., Hartley, A., Joel, G., Penuelas, J. and Valentini, R. (1995). Relationships between NDVI, canopy structure and photosynthesis in three Californian vegetation types. Ecol. Appl. 5: 28-41.

Glenn, E.P., Morino, K., Didan, K., Jordan, F., Carroll, K.C., Nagler, P.L., Hultine, K., Sheader, L. and Waugh, J. (2008). Scaling sap flux measurements of grazed and ungrazed shrub communities with fine and coarse-resolution remote sensing. Ecohydrology 1: 316-329. 
Huete, A.R. and Glenn, E.P. (2011). Remote sensing of ecosystem structure and function. In Advances in Environmental Remote Sensing, Weng Q (ed). CRC Press: Boca Raton, Florida; 291320.

Hunsaker, D.J., Pinter-Jr, P.J. and Kimball, B.A. (2005).Wheat basal crop coefficients determined by normalized difference vegetation index. Irrig. Sci. 24: 1-14.

Irmak, S. (2010). Nebraska water and energy flux measurement, modeling, and research network (NEBFLUX). Trans. ASABE 53: $1097-1115$.

Jiang, L. and Islam, S. (1999). A methodology for estimation of surface evapotranspiration overlarge areas using remote sensing observations. Geophys. Res. Lett. 26 (17): 2773-2776.

Jiang, L. and Islam, S. (2001). Estimation of surface evaporation map over Southern Great Plains using remote sensing data. Water Resour. Res. 37 (2), 329-340.

Jiang, L. and Islam, S. (2003). An intercomparison of regional latent heat flux estimation using remote sensing data. Int. J. Remote Sens. 24 (11): 2221-2236.

Justice, C.O. and Townshend, J.R.G. (2002). Special issue on the Moderate Resolution Imaging Spectroradiometer (MODIS): A new generation of land surface monitoring. Remote Sens. Environ. 83: 1-2.

Kamble, B., Kilic, A. and Hubbard, K. (2013). Estimating Crop Coefficients Using Remote Sensing-Based Vegetation Index. Remote Sens. 5(4): 1588-1602.

Moran, M.S., Clarke, T.R., Inoue, Y. and Vidal, A. (1994). Estimating crop water deficit using the relation between surface air temperature and spectral vegetation index, Remote Sens. Environ. 49: $246-263$ 
Neale, C.M.U. (1983). Monitoring corn development using reflected radiation. M.S. Thesis, Colorado State University, Fort Collins: 134.

Rouse, J.W., Hass, R.H., Schell, J.A. and Deering, D.W. (1973). Monitoring vegetation systems in the great plains with ERTS. Third ERTS Symposium, NASA SP-351, 1: 309-317.

Sellers, P.J. (1985). Canopy reflectance, photosynthesis and transpiration. Int. J. Remote Sens. 6, 1335-1372.

Shahidian, S., Serralheiro, R., Teixeira, J.L., Santos, F.L., Oliveira, M.R., Costa, J., Toureiro, C., Haie, N. and Machado, R. (2009). Drip Irrigation using a PLC based Adaptive Irrigation System WSEAS Transactions on Environment and Development, 2.

Tasumi, M. and Allen, R.G. (2007). Satellite-Based ET Mapping to Assess Variation in ET with Timing of Crop Development.

Agricultural Water Management, 88, 54-62.

Tucker, C.J. (1979). Red and photographic infrared linear combinations for monitoring vegetation. Remote Sens. Environ. 8: 127-150.

Yoder, B.J. and Waring, R.H. (1994). The normalized difference vegetation index of small Douglas fir canopies with varying chlorophyll concentrations, Remote Sensing Environ. 49: 81-91.

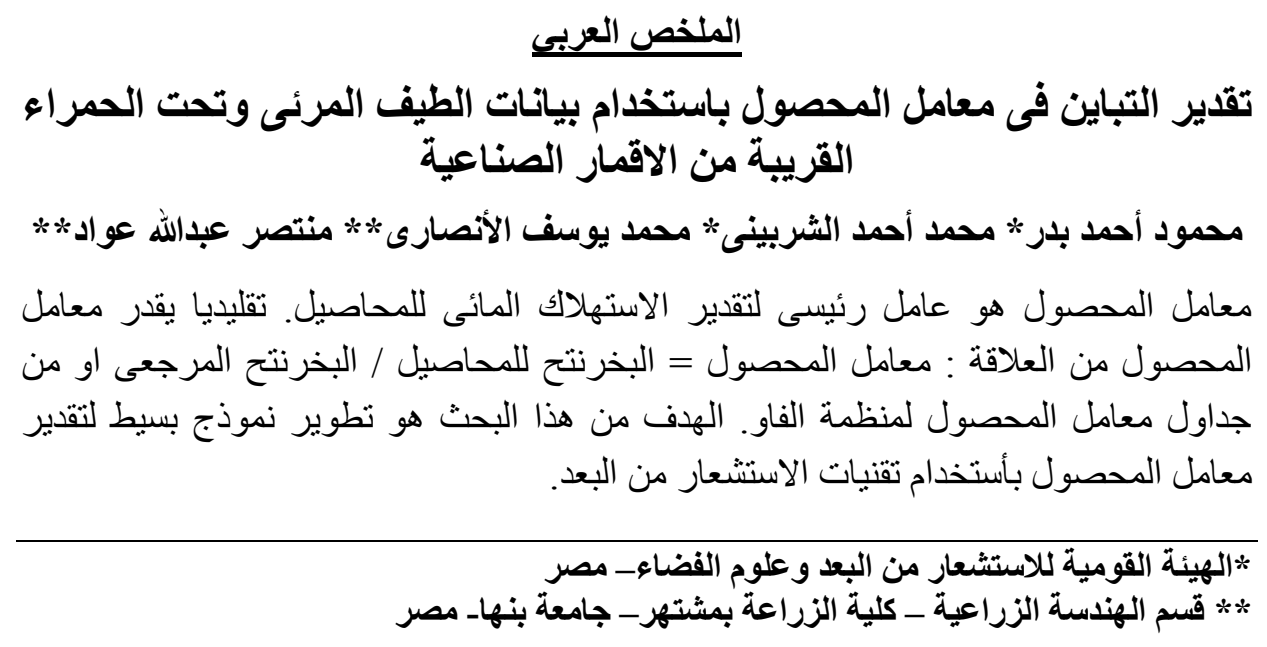


لتطوير هذا النموذج تم اقامة هذا العمل فى منطقة الصالحية على ثلاث محاصيل شتوية القمح،

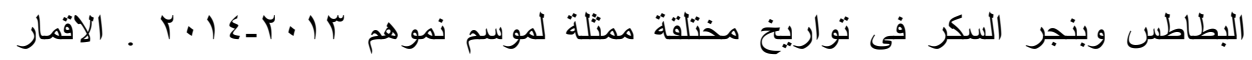

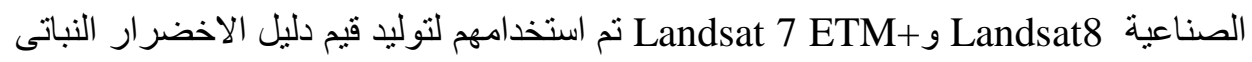

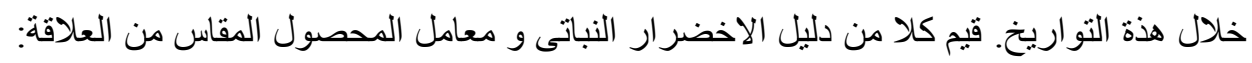

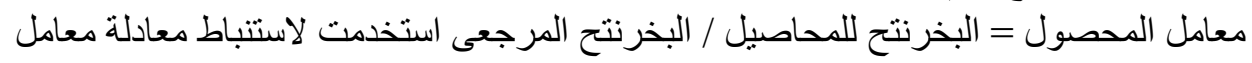

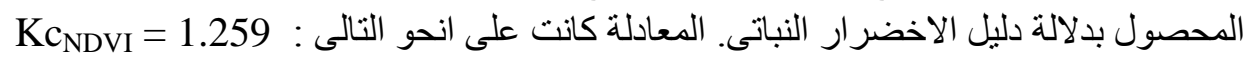

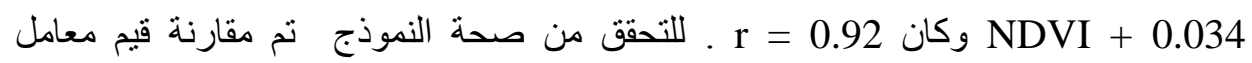

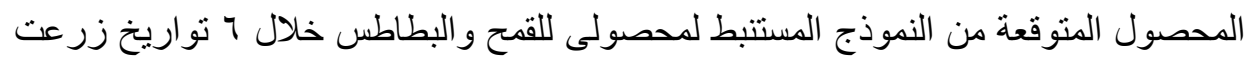

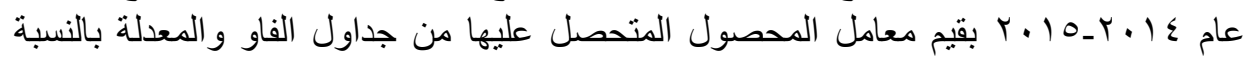

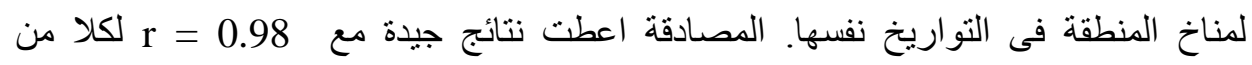

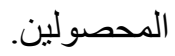

